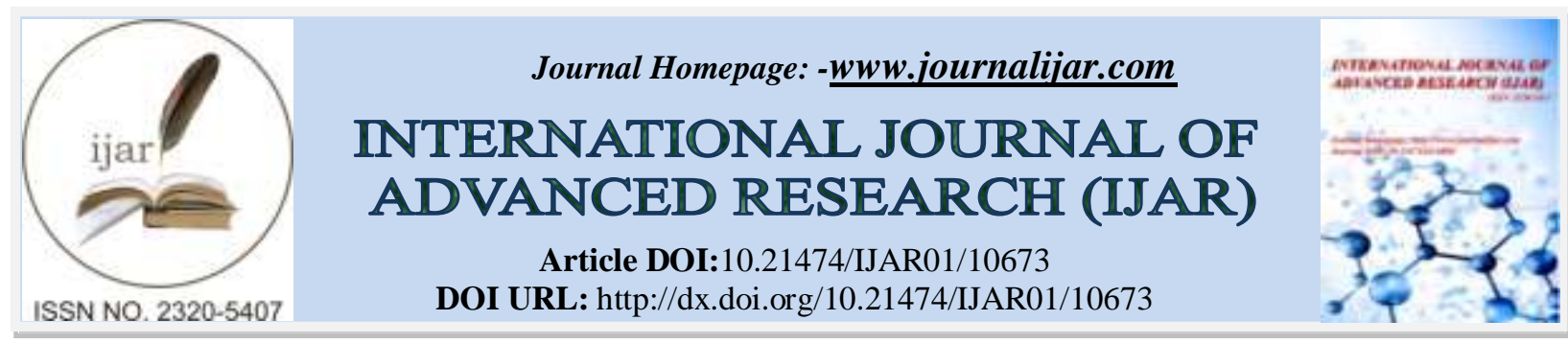

RESEARCH ARTICLE

\title{
EFFECTS OF PRINCIPALS' INSTRUCTIONAL SUPERVISORY PRACTICES ON STUDENTS' ACADEMIC PERFORMANCE IN PUBLIC SECONDARY SCHOOLS IN MACHAKOS COUNTY, KENYA
}

\author{
Kavita Bonface Mutiso ${ }^{1}$, Dr. Francis Kirimi ${ }^{2}$ and Dr. Florence Itegi $^{2}$ \\ 1. Miumbuni A.I.C secondary school, P.O.BOX, 150-90104, Mitaboni, Kenya. \\ 2. Kenyatta University, P.O. BOX, 43844, Nairobi, Kenya.
}

\section{Manuscript Info}

Manuscript History

Received: 15 January 2020

Final Accepted: 17 February 2020

Published: March 2020

Key words:-

Instructional Supervisory Practices, Principals, Academic Performance

\begin{abstract}
Studies have globally, regionally and nationally demonstrated that principals do not practice effectively various supervisory practices. Despite the continued efforts by the Kenyan government to institute policies to mitigate this problem, students' performance in Machakos remain low over the last five years. The purpose of this study was therefore to investigate the relationship between principals' instructional supervisory practices and students' performance in public secondary schools in Machakos County. Descriptive survey design was adopted, simple random sampling and stratified sampling were used to select target population of 8 sub county QASOs, 47 principals and 395 teachers of public secondary schools within Machakos County, Kenya. Both descriptive (mean and standard deviation) and inferential statistics (independent t-test) were used in the analysis of quantitative data. Qualitative data was analysed thematically and through narration. Questionnaires and interview guides were employed in data collection process. The study established that, principals did not enhance mentoring, classroom observation and peer teaching among teachers. The study recommends that the government should enhance termly inservice training programmes to train teachers on the use of various supervisory practices among teachers.
\end{abstract}

Copy Right, IJAR, 2020,. All rights reserved.

\section{Introduction:-}

Instructional Supervision Practices and Students' Performance:

Instructional supervisory practices are procedures employed by principals to guide teachers on effective teaching and learning process. These practices include peer teaching among teachers, classroom observation by principals, checking teachers' professional documents and mentoring among teachers. In a study on instructional supervisory practices and teachers' role effectiveness in Calabar south local government area of cross river state, Nigeria, Anike, Eyiene and Egbai (2015) who used ex post facto design and sampled principals and teachers established that, there is a positive significant correlation between instructional supervisory practices and teachers' role effectiveness. In that regard, there was a need for this study to explore the role of instructional supervisory practices on learners' classroom achievements in Kenyan context thus revealing the pattern of supervisory practices in the study locale.Several studies in Kenya have demonstrated limited implementation of principals' supervisory practices like 
peer teaching, mentoring and classroom observation (Mutuku, 2018' Musyoka, 2018, Mohhamedsiraj, 2013 and Muthoka, 2014).

A study by Samoei (2014) in Nandi within Kenya established that principals did no observe teachers in class. Further preparation of lesson plans by teachers was not done at all at secondary school level. This raised a pertinent question as to whether supervisory practices by principals were fully practised. This is because without effective supervision practices by principals was bound to lead to low students' achievements. This is because as established by Wanzare (2012), instructional supervisory procedures and practices improve quality of teaching and learning, enabling teachers to identify teaching and learning problems. It is therefore evident that for an effective teaching and learning to be realised, principals should actively supervise teachers and help them to instruct in an effective way hence enhancing learners' performance.

In a study conducted in Kenya by Namunga (2017) involving a sample of principals, teachers and prefects, using Glatthorn's theory of differentiated supervision and using questionnaire and interview schedule as instruments, it was established that there is a limited utilisation of induction and classroom observation by the principals. This raised concern as to whether instructional supervision practices by principals like peer observation and checking of teachers' professional documents was being practised. Inappropriate use of these instructional supervisory practices means that, teachers may have insufficient skills on how to instruct effectively which may later be transferred to students' classroom performance. In line with this, a need therefore arose to sample principals, teachers and Quality, and Standards Officers (QASOs) and their opinion was sought with regard to principals' instructional supervisory practices and their influence on students' academic performance. Further, this study was guided by classical theory of management by Fredrick Taylor (1911) in order to guide on how effective instructional supervision should be conducted.

This study acknowledges that there could be many extraneous variable which may affect students' academic performance. However, these variables will be held constant in order to explore the influence of principals' supervisory practices on students' performance.

\section{Clinical Supervision by the principals and students' performance:}

Clinical supervision is a well-planned and a progressive process which starts outside the classroom before the actual teaching and ends outside the classroom after the teaching. It has three phases namely pre observation conference, observation conference and post observation conference Cogan (1973). Pre observation conference involves the supervisor developing rapport with the teachers by way of greeting them and receiving the lesson plan which then guides the lesson presentation. This stage in other words creates friendly environment thus making the supervisor approachable. Secondly, in the observation conference, the supervisor sits in a class and observes the teacher as he/she delivers. The teacher is evaluated on teaching methodology, chalkboard use and mastery of the content in class. Eventually in the post observation is done at the end of the lesson where the supervisor advises the teacher on areas of improvement. This happens on a private place where the teacher is advised on areas of improvement during subsequent lessons.

The use of clinical supervision helps a teacher to have confidence and deliver content well during teaching. This ensures that lesson objectives are effectively achieved within the stipulated time hence helping the learner improve academically. A study by Wanzare (2013) and Adimasu (2014) on skills and attributes of instructional supervisor: Experience from Kenya and Nigeria respectively which adopted descriptive survey design and sampled 213 respondents who included provincial directors of education, district educational officers and quality assurance officers (QASOs) established that, supervisors do not regard holding conferences with teachers especially after classroom observation. Further, the study indicated that, a case where this post observation conference is held, it always dominated by the supervisor leaving the teacher with limited time to point out areas which he/she thought required improvement. A situation where the teacher is denied an opportunity to express area of difficulties in teaching and learning implies that those areas of inadequacies won't be addressed fully leading to ineffective teaching in class, which may later spill over to students' poor performance in their examinations. This study therefore selected relatively larger sample of 415 respondents which will included principals, teachers and QASOs to explore the manner in which clinical supervision is conducted and its influence on learner performance in Machakos County. This adequate sample ensured that the findings on how clinical supervision is conducted in relation to students' performance in Machakos county was well generalised. 
In a study by Samoei (2014) on instructional supervisory role of principals and its influence on students' academic achievement in public secondary schools in Nandi north district in Kenya which adopted psychological theory of supervision established that, $66.7 \%$ of the principals never visited teachers in classrooms to observe teachers lessons and provide feedback. This implied that teachers were not in a position to learn from the wealth of experience from those supervisors on how to instruct effectively and improve on their teaching after the feedback. This subsequently implied that learners were not able to achieve lesson objectives better. This study thus adopted classical theory of management to help explore whether efficiency in teaching is being achieved by use of principals' creativity, innovation and specialisation in instructional practices.

\section{Mentoring as Instructional Practice on Students' Performance:}

According to Abiddin (2006), mentoring relates to self-development, professional growth and career development of the supervisee. The mentor's role is to help learners achieve their goal by acting as a facilitator, advisor and a guide. In this regard, mentor is an experienced teacher who teaches a fairly less experienced teacher on how to embrace high quality teaching which in extension may enhance good students' academic performance. Highly experienced teacher happens to be the principals who should teach the student in a personal and close long-term relationship that allows critical concentration on the task performance of classroom teaching.

In a study on the current practices of instructional supervision: the case of secondary schools in Harari region, in Ethiopia, Dechassa (2011) which adopted descriptive survey design, used 182 respondents (teachers and supervisor committee) established that, $34.7 \%$ of the teachers were never provided with mentoring. This is serious limitation in teaching and learning because there is much need for principals who have fairly many years in teaching service to guide new teachers at a close range and on a long term basis on how effective teaching and learning should be done. A case where mentoring lacks, then it implies that there is a probability that teachers may not offer quality teaching and learning which ultimately is likely to manifest itself on decline in students' achievement. This is in line with Abera (2014) in his study on mentoring in Nigeria that, having a mentor will contribute to mentee job satisfaction and also it contributes to mentee job satisfaction and later enhance quality teaching which eventually may enhance learners' academic performance. It was therefore necessary to conduct a study in a Kenyan within Machakos county setting and examine the practice of mentoring by principals to teachers and whether it enhances learners' academic achievement.

In a study on problems of mentoring, Abdullah (2016) indicates that, generally many participants know little about decent mentoring, there is also limited interest on the role of mentoring and lastly, no criteria seem to be applied in the selection of mentors. In that regard, a need therefore arose to examine as to how mentoring as a practice in instructional supervision is conducted by the principals in Machakos County. The study established the level of qualification of the mentors (principals) and also found out whether teachers have the knowledge on the role of mentoring as an instructional supervision with reference to students' performance.

Abera (2014) further highlights that, one of the major challenge facing mentoring is unhealthy mentee and mentor relationship. A case where the teacher (mentee) doesn't relate well with the mentor (principal) means that it will be quite hard for the teacher to seek guidance from the mentor because of fear hence leading to poor teaching process which may later spill over to students' performance. In this regard, a need arose to examine how teachers and principals relates and whether this relationship influenced students' academic performance in a classroom setting. Further, Abera(2014) too established that there is limited feedback on the mentor to mentee on their progress in instruction processs.In a situation where there is limited feedback from the mentor to mentee means that corrective measures are not likely to be addressed leading to the teacher failing to know the areas to improve and how. It is on this basis that the study meant to establish in the event that mentoring has been conducted, then how has been the frequency of feedback between the principal and the teacher in Machakos County public secondary schools.

\section{Peer Observation as Instructional Practice and Students' Performance:}

Peer observation is a reciprocal arrangement in which peers work together for mutual benefits, where developmental feedback is emphasized and self-directed learning and evaluation is encouraged (Benshoff, 1992). It is therefore a process where the principal as instructional supervisor organizes teachers inform of groups to observe each other as they teach in classes, give feedback to each other and encourage one another. Carrol and Gilbert (2005) observes that, peer observation has several advantages like, one may hear the work of group members which may be different from his/hers hence gaining knowledge by proxy, enables meaningful networking, helps to develop a professional 
identity and lastly other group members may well have knowledge and experience that the rest of the group members may not have.

Examining the above definition, peer observation involves majorly teachers in the same level in terms of teaching experience, who come together to complement each other in a group set up. Each teacher is given a chance to teach while others take notes on his teaching methodology to advice after the class. In a study on the impact of peer tutoring on learning of students in Pakistan, Ali, Anwer and Abbas (2015) demonstrated that, peer teaching enables the learner to get attention and self-confidence. This implies that, when teachers peer teach each other, they are free and open to correct each other hence attaining better teaching skills which later on improve learners' classroom performance. It was therefore necessary to conduct this study in Machakos County, Kenya on the effectiveness of peer teaching on learners' performance.

However, Carroll and Gilbert (2005) cautions that peer supervision may often face various challenges. These may include: groups could lack structure and degenerate into gossip sessions, chats or discussions groups, other demands on peoples' time could impact on the attendance, people could feel demoralised or criticised hence discouraging them, individuals may dominate and others become passive and lastly ensuring there is sufficient time to meet the supervision needs of the group may be a challenge. The study sought to find out in case peer teaching has been facing above mentioned problems, what could be the possible intervention in order to achieve high quality teaching and learning leading to improvement in students' academic achievement.

\section{Checking Teachers' Professional Documents and Learners' Performance:}

Any teacher should be in a position to prepare lesson plans, schemes of work, mark students books and prepare the record of work covered. It is the responsibility of the principal to ensure that all teachers prepare the above said documents (Republic of Kenya, Ministry of education, 1979). These teaching professional documents helps the teacher to plan well and spent time effectively in the teaching of designated lesson objectives effectively.

In a study on instructional supervisory role of principals and its influence on students' academic achievement in public secondary schools in Nandi north Sub County, Samoei (2014) which adopted mixed approach as a research design and used descriptive statistics established that, $95 \%$ of teachers do not prepare lesson plans. The lesson plans were substituted with teachers' guide books. This discouraged quality teaching and learning because preparation of lesson plan in advance gives the teacher opportunity to think out the best methods of achieving his/her aim within forty minutes and maintaining the interest and activity of the learners. This study employed descriptive survey design in order to describe the true picture of how principals checked teaching professional documents (Ono and Onen, 2005). Additionally, this study employed both descriptive and inferential statistics to enhance generalizability of findings (Orodho et al, 2016b). Limited supervision of these teaching professional documents means that students' achievements in class may not be realised. This is because according to the study on instructional supervisory practices and teachers' role effectiveness in public secondary schools in Calabar, Nigeria, Anike, Eyiene \& Egbai (2015) demonstrated that, there is a positive significant relationship between instructional supervisory practice of checking teachers lesson notes and teachers role effectiveness. This meant that, the more the principal checks teachers' lesson notes, the more they deliver effectively in class hence leading to high students' academic achievement.

\section{Statement to the problem:}

Principals' instructional supervisory practices enhance learners' classroom achievement. The Kenyan government has continuously engaged principals in many in-service training for them to be guided on effective implementation of various supervisory practices. Despite the above stated efforts, studies continue to reveal limited implementation of supervisory practices by principals locally, nationally, regionally and globally. According to County Director of Education in Machakos, the average performance in KCSE has been extremely low for the last five years. Continued underperformance of KCSE in Machakos County has been a great concern for many people. If the issue of academic performance in this county will not be addressed, academic opportunities for learners in their careers may be closed. The purpose of this paper was therefore to explore the relationship between principals' supervisory practices and learners' performance in public secondary schools within Machakos County. This paper may be significant for it will reveal the manner in which instructional resources are provided in schools thus recommending possible interventions to address this research problem. 


\section{Objective of the Study:-}

The objective of this study was to:

(i)Investigate supervisory practices by principals and students' performance in Machakos County.

\section{Hypothesis of the study}

$\mathrm{H}_{01}$ : There is no statistically significant relationship between principals' supervisory practices and students' performance.

\section{Theoretical Framework:}

The study was anchored on classical scientific management theory by Taylor (1911) in its attempt to explain the influence of principals' instructional supervisory practices on students' academic performance of public secondary schools in Machakos County, Kenya. According to Robbins, Bergman \& Coulter (2006), in order to ensure maximum efficiency and output in production in any organisation, classical scientific management theory ensures that workers are scientifically selected, trained and taught to the greatest efficiency.

According to the principle that workers (principals) should be scientifically selected, trained, taught and developed to their greatest efficiency (students' performance), the study examined whether instructional supervisors in public secondary schools within Machakos County had specialised training skills in instructional supervision and whether by using such supervisory skills enhanced effective instructional supervisory practices. In the event that they had low professional qualification and attended limited in service programmes on supervision of teaching, it implied that they were unable to conduct effectively various instructional supervisory practices which might be attributed to low students' performance.

\section{Research Methodology:-}

The study employed descriptive survey design. The design was appropriate because it helped to describe the types of instructional supervisory practices as they are (Kombo and Tromp, 2006) in this study locale. Data collection instruments involved both questionnaires and interview guides. Questionnaires ensured the researcher could collect a lot of information within limited time and also it was economical (Mugenda and Mugenda, 2013). Interview guide enabled the researcher to probe more questions from QASOs in order to answer accurately research questions (Kothari, 2003).Use of the two methods ensured that each could complement each other's inadequacies thus promoting reliability of study findings (Adami, 2005).

The target population comprised of 8 Sub county Quality and standards officers who were automatically included in the study (census sampling). The researcher preferred this sampling procedure because each sub county is unique in the manner in which principals provide instructional supervisory practices thus enhancing generalizability of study findings (Oso and Onen, 2005). Secondly, there were 366 public secondary schools which were stratified as 139 mixed day and boarding, 160 mixed day and 67 boys'/ girl schools. Stratified sampling was preferred because it enabled representation of the minor groups in the population (Kombo and Trump, 2006). Using a target population of 366 principals and 5,524teachers, the researcher categorised it into two independent groups. Thirdly, stratified sampling was employed to select schools for the study. In line with this, the researcher stratified the three categories of schools into three groups, namely: mixed day, mixed day and boarding and single gender schools. This ensured that sub groups of the school were proportionately represented (Oso and Onen, 2005) hence enhancing generalizability of the study findings. According to the County director of education office in Machakos, this particular County has 369 public secondary schools. The schools comprise of 139 mixed day, 160 mixed day/ boarding and 67 single gender schools (boys' and girls' boarding). This implies that the schools are diverse in nature thus they could give information regarding principals' effectiveness on enhancement of supervisory practices. This is based on Kombo and Tromp (2006) findings who observed that, capturing variability of population allows more reliability to the study. As Mugenda and Mugenda (2013) observed, for a target population of less than 10,000 informants like in this study, the following formula was used to select the sample. $\mathrm{NF}=\frac{\mathrm{n}}{1+\mathrm{n} / \mathrm{N}}$ where $\mathrm{NF}$ was the required sample size, $\mathrm{n}$ is the sample size if target population was over 10,000 and $\mathrm{N}$ is the size of the target population. Using this formula, the sample size was computed and it resulted to 362 teachers and 45 principals. The names of the three categories of schools were written on a paper, folded and put into three bowls as per the strata. Each of the strata was proportionately represented in the sampling frame. All the principals in the sampled schools were included in the study plus the 8 QASOs from each of the eight sub counties within Machakos County. Additionally, each school which were sampled for the study had eight teachers selected for the study through simple 
random sampling to enhance generalized findings of the data (Kothari, 2004). The sample size therefore resulted to 407 informants as indicated in the table2.1.

Table 2.1:- Sampling frame for the study.

\begin{tabular}{|c|c|c|c|}
\hline School category & & e size & \\
\hline Mixed day and boarding & Principals & Teachers & Totals \\
\hline Mixed day & $17(38 \%)$ & $138(38 \%)$ & 155 \\
\hline Single gender & $20(44 \%)$ & $158(43 \%)$ & 178 \\
\hline & $08(18 \%)$ & $66(19 \%)$ & 74 \\
\hline Total & $45(100 \%)$ & $362(100 \%)$ & 407 \\
\hline
\end{tabular}

Quantitative data was analysed using both descriptive (mean, frequency and percentages) and inferential statistics (Independent t-test). The independent t-test was used to test whether there was significant differences between the means of respondents (teachers and principals) based on a 5 point likert scale. The scale was on the level of respondents; agreement as: 5-Strongly Agree, 4-Agree, 3-Neutral, 2Dissagree and 1-Strngly Disagree. The use of this inferential statistics reduced the chances of making type one error in testing the study hypothesis (Kothari, 2004). Qualitative data was analysed thematically to enrich quantitative data.

\section{Data Presentation, Interpretation and Discussion:- General and Demographic Information: Return rate:}

A total of 415 informants were targeted for the study (including 45 principals, 362 teachers and 8 sub county QASOs). Out of those, 394 informants responded including 38 principals, 349 teachers and 7 sub county QASOs. Seven principals were not present in schools during data collection period while 13 teachers were unable to report to the questionnaire because they were absent due to games activities during data collection process. One of the sub county QASO was unwell at hospital hence he could not be interviewed. This resulted to a response rate of $94.9 \%$. Mugenda and Mugenda (2013) recommends that $60 \%$ to be a good response rate hence the researcher took it that it had met the threshold thus enhancing generalizability of the study findings. This is because the findings were considered to be free from participation bias and non-response error.

\section{Demographic Information of the Informants:}

Principals and teachers were asked to indicate their gender on the research instruments. The responses were given in the table below.

Gender of informants:

Table 3.1:- Distribution of informants by gender.

\begin{tabular}{|l|cc|cc|ccc|}
\hline Gender & QASOs & Principals & \multicolumn{3}{|c|}{ Teachers } \\
\hline & $\mathrm{F}$ & $\%$ & $\mathrm{~F}$ & $\%$ & & $\mathrm{~F}$ & $\%$ \\
Male & 6 & 86 & 22 & 58 & 206 & 59 \\
Female & 1 & 14 & 16 & 42 & 143 & 41 \\
\hline Total & 7 & 100 & 38 & 100 & \multicolumn{2}{|c|}{349} & 100 \\
\hline
\end{tabular}

Basing on the findings in table 3.1, the study seems to suggest that more than half of the principals $22(58 \%)$ are males while more than a third $16(42 \%)$ are females. It is therefore evident that the principals in this County are dominated by males. Despite this, the study findings reveal that, one third requirement for either gender to be in administrative positions within public secondary schools has been achieved in Machakos County. This finding ties well with studies by Mutuku (2018) and Musyoka (2018) which were conducted in Machakos County establishing that more than half of the principals were males.

Interestingly, more than three quarters $7(86 \%)$ of the QASOs were all males. This meant that this position is also dominated by males as opposed to females who were represented by one informant. More than half 206 (59\%) of the teachers were males whereas only $143(41 \%)$ represented female teachers. The study finding seem to indicate that teaching profession in this County has males as majority. 
The respondents were also required to indicate their highest level of professional qualification. The findings are presented in table 3.2.

\begin{tabular}{|c|c|c|c|c|c|c|c|c|}
\hline \multirow[b]{2}{*}{ Respondents } & \multicolumn{2}{|c|}{ PhD } & \multicolumn{2}{|c|}{ Masters } & \multicolumn{2}{|c|}{ Bachelors } & \multicolumn{2}{|c|}{ Diplomas } \\
\hline & $\mathbf{F}$ & $\%$ & $\mathrm{~F}$ & $\%$ & $\mathrm{~F}$ & $\%$ & $\mathrm{~F}$ & $\%$ \\
\hline Principals & 0 & 0 & 11 & 29 & 27 & 71 & & 0 \\
\hline Teachers & 0 & 0 & 29 & 8 & 234 & 67 & 86 & 25 \\
\hline QASOs & 0 & 0 & 04 & 57 & & 43 & 00 & 0 \\
\hline Total & 0 & 0 & 44 & 100 & 26 & 100 & 86 & 100 \\
\hline
\end{tabular}

Surprisingly, more than half of the QASOs 4 (57\%) had master of education degree. In that regard, QASOs were relatively more qualified than principals and teachers in Machakos County. The fact that majority of QASOs had master's degree may be attributed to the fact that, for one to hold QASO position, a competitive vetting process was conducted favouring candidates with higher educational levels. Secondly, the study suggested that all the principals had attained either bachelor of education degree or master's degree compared to teachers who only majority of them $234(67 \%)$ had attained undergraduate degree in education. The finding demonstrates that principals were more qualified compared to teachers. Further, it may be taken that majority of the informants (QASOs, principals and teachers) had minimum qualification which is diploma (Wanjiru, 2019), hence they had knowledge on principals' supervision and could provide reliable data with regard to study objective. Unexpectedly, none of the informants who were sampled for the study had attained a doctorate of philosophy degree. This may be explained by the high university fees required for one to take $\mathrm{PhD}$ programmes compared to masters and undergraduate degree programmes.

Distribution of Informants by Duration of Service in Schools:

The informants were requested to indicate their length of stay in the teaching profession. Table 3.3 demonstrates both teachers' and principals' length of stay in their instruction profession.

\begin{tabular}{|l|cc|cc|}
\hline \multirow{2}{*}{ Duration } & Principals & Teachers & \\
\cline { 2 - 5 } & F & \% & F & \% \\
\hline $0-2$ years & 0 & 0 & 41 & 12 \\
$3-10$ years & 00 & & 231 & 67 \\
11 years and above & 38 & 100 & 73 & 21 \\
\hline Total & 38 & 100 & 345 & 100 \\
\hline
\end{tabular}

Findings in table 3.3 indicates that all the principals $(38,100 \%)$ had worked for more than ten years. This finding probably demonstrates that, for any teacher to become a principal, one had to have taught for several years in order to gain supervision experience hence more years in the teaching service. Additionally, table 4.3 shows that more than two- thirds of the teachers $(231,67 \%)$ had teaching experience of more than three years and ten years. This implies that teachers had therefore stayed in their work station through four years in which a student enters the school in form one, is influenced by principals' supervisory practices and graduates in form four. Informants therefore had adequate time to observe and make correct judgements on various instructional supervisory practices and its effect on students' performance. Similar pattern of results was reached by various studies by Mohhamedsiraj (2015), Muthoka (2014) and Samoei (2014) that majority of teachers in schools had more than nine years in teaching service.

Principals' Instructional Supervisory Practices and Students' Academic Performance:

On the first research question, the informants were asked to indicate their level of agreement on how principals practice various instructional supervisory practices. A five point likert scale was used to indicate their agreement level as follows: Strongly Agree $(S A)=5$, Agree $(A)=4$, Neutral $(N)=3$, Disagree $(D)=2$ and Strongly Disagree $(\mathrm{SD})=1$.

Table 3.4:- Respondents' views on the principals' supervisory practices.

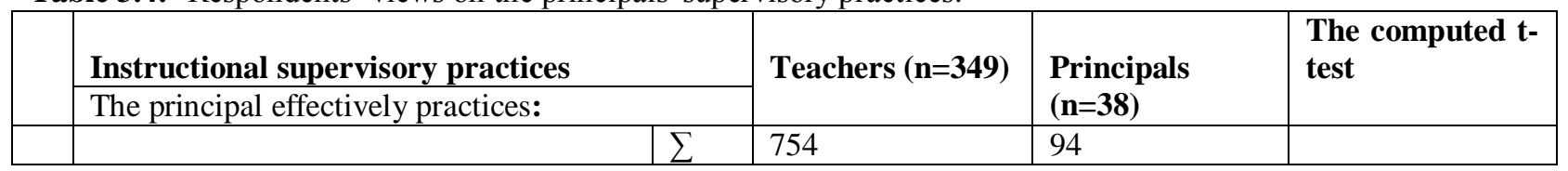




\begin{tabular}{|c|c|c|c|c|c|}
\hline 1 & \multirow[t]{2}{*}{ Classroom observation } & $\mathrm{M}$ & 2.16 & 2.47 & \multirow[t]{2}{*}{0.913} \\
\hline & & S.D & 1.15 & 0.79 & \\
\hline \multirow{3}{*}{2} & \multirow{3}{*}{ Mentoring among teachers } & $\sum$ & 701 & 94 & \multirow{3}{*}{1.273} \\
\hline & & $\mathrm{M}$ & 2.01 & 2.48 & \\
\hline & & S.D & 0.34 & 1.62 & \\
\hline \multirow{3}{*}{3} & \multirow{3}{*}{ Peer teaching among teachers } & $\sum$ & 677 & 94 & \multirow{3}{*}{1.331} \\
\hline & & $\bar{M}$ & 1.94 & 2.47 & \\
\hline & & S.D & 1.13 & 0.78 & \\
\hline \multirow{3}{*}{4} & \multirow{3}{*}{$\begin{array}{l}\text { Checking of teachers' professional } \\
\text { documents }\end{array}$} & $\sum$ & 1452 & 172 & \multirow{3}{*}{0.977} \\
\hline & & $\bar{M}$ & 4.16 & 4.53 & \\
\hline & & S.D & 0.64 & 1.27 & \\
\hline
\end{tabular}

NB:* indicates that there is a statistically significant difference at $\alpha=0.05$ with degrees of freedom as 386 and table value of $1.645, \sum=$ sum, $\mathrm{M}=$ Mean and $\mathrm{S} . \mathrm{D}=$ standard deviation.

Firstly, according to table 3.4, informants were asked whether principals conducted classroom observation regularly. Surprisingly the study suggested that teachers $(M=2.16, S . D=1.15)$ and principals $(M=2.47, S . D=0.79)$ disagreed with this statement. The computed t-test value at $\alpha=0.05, \mathrm{p}>0.05$ and 386 as degrees of freedom was 0.913 which was less than critical value of 1.645. This implied that there was no significant difference on the level of agreement between the two groups. Similarly, one of the lady principal informant in MKD sub county, Machakos County and whose school average mean from 2014 to 2019 was 2.798 out of possible 12 points stated that management responsibilities were so demanding hence getting time to observe teachers in class was difficult for her. Such finding may be taken to imply that principals rarely observed teachers in classroom rooms. Limited classroom observation by principals may be attributed by too much administrative work by principals which make it hard for the principals to observe teachers in classes. The finding from this study that principals rarely observe teachers in classes is similar to findings by Adimasu (2014), Dechassa (2013), Mohhamedsiraj (2015) and Samoei (2014), that principals rarely visited teachers to observe them in classes.

Secondly, according to table 3.4 where informants were asked whether principals enhanced mentoring among teachers, the findings revealed that teachers $(M=2.01, S . D=0.34)$ and principals $(M=2.48, S . D=1.62)$ disagreed. Further, the calculated t- test value with 386 as degrees of freedom, $\alpha=0.05$ and $p>0.05$ was 1.273 which was less than the critical value of 1.645. This in essence meant that there is no significant difference between the means of the two groups with reference to their agreement levels. One male principal as one of the informants in MWL sub County in Machakos indicated in the questionnaire that to the best of his knowledge, mentoring among teachers was rarely practiced in Machakos central sub County and because of this, many teachers did not know what it entailed. Lack of mentoring of teachers by their principals may also be revealed by the fact that teachers were not mentored on the utilisation of wall charts in the classroom to enhance good retention of knowledge by the learners. This was probably demonstrated on figure 4.1 of one of the school classrooms without any wall charts meaning that teachers relied only on chalk and book to teach therefore raising concerns on mentorship programmes offered to teachers if any.

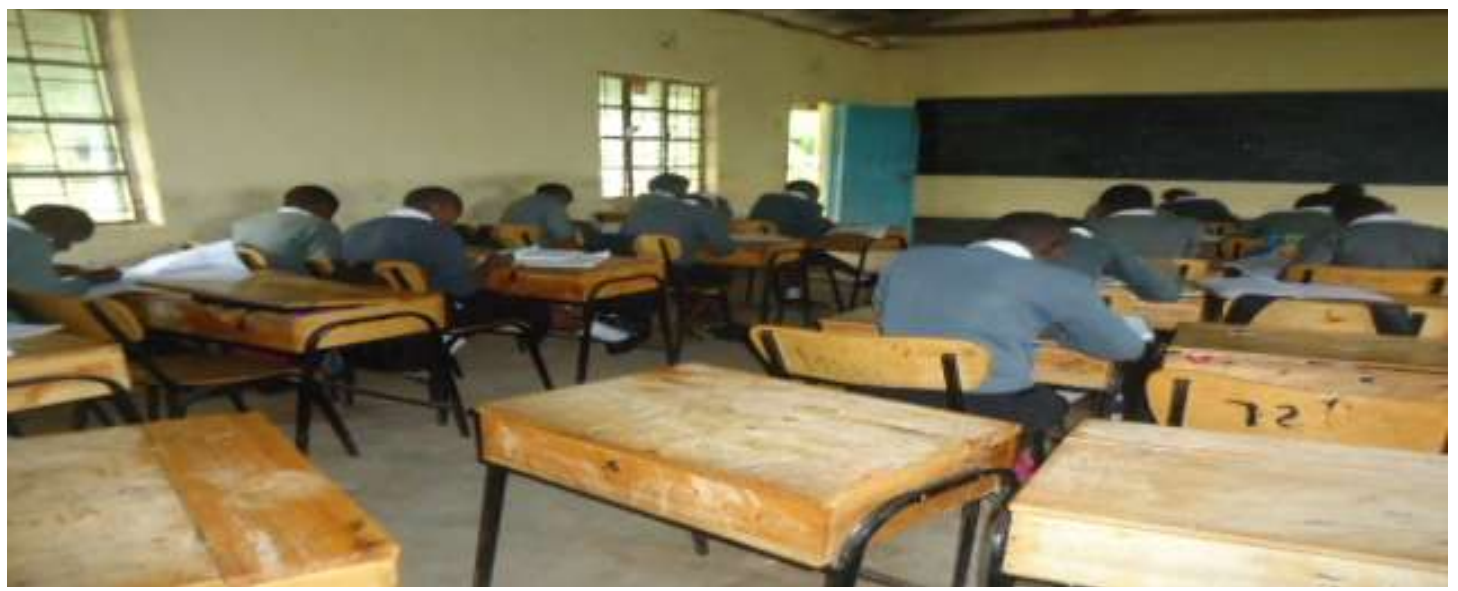

Figure 3.1:- A sample of a classroom. 
Figure 3.1 may be taken to indicate limited mentoring of teachers by their principals which probably explains the inability of teachers to enrich teaching and learning using wall charts as part of their teaching aids. Limited inservice training of teachers probably may explain why teachers have few mentorship programs if any because they are taught in those refresher courses. Using the management theory by Taylor (1911) where this study was anchored from, for efficiency to be realized, training and retraining of workers should be encouraged. It therefore means that in the context of this study, principals should expose teachers to many in-service trainings which encourages mentorship as a supervisory practice. This later on enables teachers to learn effective teaching methods from their experienced peers which eventually affects learners' classroom performance. The finding that there is limited mentorship among teachers by their principals was similar to other several studies like Arot, (2014), Dechassa, (2013) and Namunga (2017).

Thirdly, basing on table 3.4 where informants were also asked whether principals encouraged peer teaching among teachers, interestingly, teachers $(\mathrm{M}=1.94, \mathrm{~S} . \mathrm{D}=0.64)$ and principals $(\mathrm{M}=2.47, \mathrm{~S} . \mathrm{D}=0.78)$ disagreed to it. The computed t-test value with degrees of freedom as $386, \alpha=0.05$ as significance level and $p>0.05$ was 1.331 which was less than critical value of 1.645. This suggested that there was no significant difference on agreement levels of the two groups. One of the male QASO informants from MVK sub County in Machakos revealed that in his Sub County which had an average mean score of 3.454 from 2019 to 2014, little was known about peer teaching and its significance and therefore it's rarely practised. Insufficient enhancement of peer teaching in Machakos County may be attributed to the many challenges of peer teaching like teachers feeling demoralized or criticized by their peers and insufficient time to meet as peer supervisors which was established by Carroll and Gilbert (2005).

Fourthly, according to table 3.4, the informants were also asked whether principals checks teachers' professional documents. Teachers $(\mathrm{M}=4.16, \mathrm{~S} . \mathrm{D}=0.64)$, and principals $(\mathrm{M}=4.53, \mathrm{~S} . \mathrm{D}=1.27)$ agreed to this statement. The calculated t-test value was 0.977 (386 as degrees of freedom, 0.05 as significant level and $p>0.05$ ) which was less than critical table value of 0.645 . This meant that there was no significant difference on the level of respondents' agreement. Similarly, a lady principal in MVK Sub County within Machakos and who was an informant indicated in the questionnaire that TSC performance and contracting (TPAD) was on high gear and no one would ignore such teaching documents for it was so instrumental during promotion procedures for teachers in the service. The finding seem to reveal that principals check regularly teaching documents like schemes of work, lesson plans, progressive students' record and students' registers. Sufficient checking of teachers' professional documents differs from the findings by Samoei (2014) study that was conducted in Nandi County within Kenya that principals did not effectively check teachers' lesson plans and records of work covered. These findings might have differed because Samoei (2014) used 177 as sample size as opposed to this study which used 415 respondents for the purpose of enhancing generalizability of study findings (Orodho, et al 2016b).

The study sought to establish the opinion of informants as to whether instructional supervisory practices affects students' performance. Table 3.5 indicates the findings of their opinion.

Table 3.5:- Opinion of informants as to whether instructional supervisory practicescontributes to students' performance.

\begin{tabular}{|l|l|l|l|l|}
\hline Respondents & Yes & No & Undecided & Totals \\
\hline QASOs & $7(100 \%)$ & $0(0 \%)$ & $0(0 \%)$ & $07(100 \%)$ \\
\hline Principals & $38(100 \%)$ & $0(0 \%)$ & $0(0 \%)$ & $38(100 \%)$ \\
\hline Teachers & $345(99 \%)$ & $0(0 \%)$ & $4(1 \%)$ & $349(100 \%)$ \\
\hline Totals & $390(99 \%)$ & $0(0 \%)$ & $4(1 \%)$ & $394(100 \%)$ \\
\hline
\end{tabular}

Interestingly, according to table 3.5, almost all the three categories of informants, that is $(7,100 \%)$ of QASOs, $(38$, $100 \%)$ of principals and $(345,99 \%)$ of teachers agreed that instructional supervisory practices by principals influences students' academic performance. Only $(4,1 \%)$ teachers were undecided on the statement. Such a finding seems to suggest that instructional supervisory practices affects students' academic performance. Basing on the management theory by Taylor (1911) which guided this study, if any firm which in this case is public secondary school has to enhance efficiency in production which is students' performance, managers (principals) should train and retrain workers, who are teachers. It is during these in-service trainings where teachers gather new skills on effective use of supervisory practices which may eventually improve students' performance. It is therefore seemed to be evident that the findings of this study have validated this particular principle of this theory that training and retraining of workers enhance their productivity which is students' performance. Such a finding agrees well with 
studies by Adimasu (2014), Arot (2014), Musyoka (2018), Wanzare (2013) and Namunga (2017) that instructional supervisory practices have effect on students' classroom performance.

The study's null hypothesis is therefore rejected and alternative hypothesis adopted that that there is statistically significant relationship between principals' supervisory practices and students' academic performance.

\section{Summary of Findings, Conclusions And Recommendations:-}

The objective of this study required informants to indicate their level of agreement on whether principals practised regularly various instructional supervisory practises. Both teachers and principals agreed that principals checked teachers' professional documents. The results from independent t-test revealed that there was no statistically significant difference on their agreement levels. On the other side, both teachers and principals disagreed that principals enhance both peer teaching, practised classroom observation and encouraged mentoring among teachers. Informants indicated that both peer teaching and mentoring was not familiar to teachers in Machakos County. Lastly, the study revealed that majority of the respondents (QASOs, principals and teachers) agreed that instructional supervisory practices like peer teaching, mentoring and classroom observation affects students' academic performance.

The present findings of this study have demonstrated that it is clear that principals practised quite well checking of teachers' professional documents, however, they rarely practised peer teaching, classroom observation and mentoring among teachers. In light of this, it emerges that there is limited practice of various instructional supervisory practices by principals. Further, the study suggested that, use of various instructional supervisory practices influences students' academic performance in Machakos County. It should however be noted that the findings of this study can only be generalised within Machakos County and not the entire country. Since the study has established that peer teaching, classroom and mentoring among teachers were rarely practiced, the researcher recommends that MOEST in conjunction with TSC should organize on yearly basis in-service trainings where peer teaching, classroom observation and mentorship among teachers will be emphasized. This may perfect teaching skills which eventually may be replicated in students' performance. The findings of this study may be so significant for they will provide insights on the types and nature of supervisory practices within the study locale hence enabling the government to plan for effective interventions of the study recommendations.

\section{References:-}

1. Abdulah, Y. \& Akyol, B. (2016). Problems of mentoring. European journal of research On education, 2(6), 142146.

2. Abera, W. (2014). Practices and challenges of mentoring in government secondary schools Of Addis Ababa. Unpublished master's thesis, Addis Ababa University.

3. Abiddin, N. Z. (2006). Mentoring and coaching: The roles and practices. Journal of human Resource and adult learning, 2(7), 106-116.

4. Adami, M. F. (2005). Nurse researcher. Retrieved April $21^{\text {st }} 2016$ from http://dx.doi.org/10.7748/nr 2005.04.12.4.19.c5956.

5. Adimasu, G. (2014). The contribution of clinical supervision on teachers' satisfaction: The case of Homecho secondary and preparatory school in Hadya zone. Unpublished Master's thesis. Haramay University, Ethiopia.

6. Ali, N., Anwer, M. \& Abbas, J. (2015).Impact of peer tutoring on learning of students. JournalFor studies in management and planning, 1 (02), 61- 66.

7. Anike, S. M., Eyiene, A. \& Egbai, M. E. (2015).Instructional supervisory practices andTeachers' role effectiveness in government secondary schools in Calabar south Local public area of cross river state, Nigeria, 6(23), 43-47.

8. Arot, O.J. (2014). Head teachers' instructional supervision practices and challenges they faceIn public primary Schools in Asego Division of Homa Bay county.Unpublished Master's Thesis. Kenyatta University.

9. Benshoff, J. M. (1992).Peer consultations for professional counsellors. Retrieved June $29^{\text {th }} 2017$ from Ann Arbor: mi: Eric/Class.

10. Carrol, M. \& Gilbert, M. (2005).On being a supervisee: Creating learning partinerships.Victoria, Australia: Psychoz publications.

11. Cogan, L.M. (1973). Clinical supervision. Boston: Houghton Miffin Company. 
12. Dechassa, F. (2013). The current practices of instructional supervision approaches and Teachers' professional development in secondary schools of Bale zone of Oromia region. Unpublished master's thesis. Haramaya University.

13. Kombo, D.K. \& Tromp, L. A. (2006). Proposal and Thesis writing, an introduction. Nairobi, Kenya: Pauline's publication Africa.

14. Kothari, C.R. (2004).Research methodology and techniques. New Delhi: New age international Limited.

15. Mohhamedsiraj, H. (2015). The practices of instructional supervision in government Preparatory schools of Arsi zone Oromia regional state.Unpblished Master's thesis. Haramaya University.

16. Musyoka, J. M. (2018). School based factors influencing students' performance in KCSE in Public secondary schools in Kathiani Sub County. Unpublished Master's Thesis, South, eastern Kenya University.

17. Mugenda, O.M. \& Mugenda, A. G. (2013). Research methods: Qualitative and quantitative Approach. Nairobi: Acts press.

18. Muthoka, W.S. (2014). Effectiveness of instructional supervision and its impact on primary School pupils' academic achievement in Masinga division, Machakos County. Unpublished Master's thesis. Kenyatta University.

19. Mutuku, M. P. (2018). Influence of instructional leadership practices on academicPerformance in public secondary schools in Machakos County, Kenya. Unpublished doctorate dissertation. Kenyatta University.

20. Namunga, W.N. (2017). Effects of supervision of instructional practices on teaching andLearning in secondary school in Kenya. International journal of scientific Research publications, 7(2), 418-427.

21. Orodho, J. A., Nzabalirwa, W., Odundo, P., Waweru, P.N. \& Ndayambaje, I. (2016b).Quantitative and qualitative research methods: A step by step guide to scholarly excellence.Nairobi, Kenya: Kanezja publishers and Enterprises.

22. Oso, W.Y. \&Onen, P. (2005).A general guide to writing research proposal and report ( $3^{\text {rd }}$ Ed.).Nairobi, Kenya: Jomo Kenyatta foundation.

23. Republic of Kenya, Ministry of education. (1979). A manual for heads of secondary schools in Kenya. Nairobi: Jomo Kenyatta foundation.

24. Robbins, S.P., Bergman, R., Stagg, I. \& Coulter, M. (2006).Foundations of management ( $2^{\text {nd }}$ Ed).Sydney: Prentice-Hall.

25. Samoei, C.J. (2014). Instructional supervisory role of principals and its influence on academic Achievement in public secondary schools in Nandi district, Nandi County, Kenya. Unpublished Master's thesis. Catholic university of eastern Africa.

26. Wanjiru, H. (2019). New requirements off a teacher in Kenya. Retrieved on $26^{\text {th }}$ October 2019 From $\mathrm{http} / /$ tuko.co.ke/305894.

27. Wanzare, Z. (2012).Instructional supervision in public secondary schools in Kenya. Education Management, administration and leadership, 40 (2), 188-216.

28. Wanzare, Z. (2013). Skills and attributes of instructional supervisor: Experience from Kenya, Academic journal. Educational research and reviews, 8 (204), 2270-2280. 